\title{
Growth, mortality and migratory pattern of white shrimp (Litopenaeus vannamei, Crustacea, Penaeidae) in the Carretas-Pereyra coastal lagoon system, Mexico
}

\author{
G. Rivera-Velázquez ${ }^{1}$, L.A. Soto ${ }^{2}$, I.H. Salgado-Ugarte ${ }^{3} \&$ E.J. Naranjo ${ }^{4}$ \\ 1. Lab. Acuicultura UNICACH, Ciudad Universitaria, Libramiento Norte s/n, Colonia Caleras Maciel, C.P. 29039, \\ Tuxtla Gutiérrez, Chiapas, México; grivera@unicach.edu.mx \\ 2. Instituto de Ciencias del Mar y Limnología, Universidad Nacional Autónoma de México, Ciudad Universitaria \\ México, D.F., México; 1soto@icmyl.unam.mx \\ 3. Lab. de Limnología, FES Zaragoza, UNAM, Av. 5 de Mayo y Fuerte de Loreto, Col. Ejército de Oriente, Iztapalapa. \\ C.P. 09230, México, D.F., México; isalgado@servidor.unam.mx \\ 4. El Colegio de la Frontera Sur, Carretera Panamericana y Periférico Sur s/n C. P. 29290, San Cristóbal Las Casas, \\ Chiapas, México; enaranjo@sclc.ecosur.mx
}

Received 22-III-2007. Corrected 28-IX-2007. Accepted 21-I-2008.

\begin{abstract}
The growth, mortality and migration pattern of the population of Litopenaeus vannamei Boone 1931 in the Carretas-Pereyra coastal lagoon system, Mexico, were studied. The shrimp spatial distribution and abundance were analyzed in relation to salinity, water temperature, and substrate. A total of 2669 shrimps was collected at 22 sites sampled monthly from March 2004 to August 2005. Juvenile shrimps of L. vannamei were present in the coastal lagoon system throughout the year, reaching densities from 0.001 to $0.302 \mathrm{ind} / \mathrm{m}^{2}$. The estimated daily growth rate was 0.06 to $0.27 \mathrm{~mm}$ carapace length (CL). No significant seasonal differences were appreciated. Weekly total mortality $(Z)$ was between 0.04 and 0.34 . Recruits, juveniles and sub-adults displayed a bimodal distributional pattern regulated by the prevailing conditions during the dry season. The peak abundance of juvenile stages occurred in December-January and March-May. The abundance presented an inverse correlation with salinity $(r=-0.42 ; \mathrm{p}<0.05)$ and a positive correlation $(\mathrm{r}=0.44 ; \mathrm{p}<0.05)$ with silt content. No clear correlation was distinguished for emigration size with season of the year or water temperature. Rev. Biol. Trop. 56 (2): 523-533. Epub 2008 June 30.
\end{abstract}

Key words: Litopenaeus vannamei, population dynamics, coastal lagoons, Mexico.

Coastal lagoons and estuaries serve as nursery habitats to an assorted number of marine species, including fish and invertebrates that are commercially exploited. These important habitats provide food and protection to estuarine-dependent species regulating their growth and survival (Pérez-Castañeda and Defeo 2001) and contributing to sustain the production of artisanal fisheries usually developed in these habitats (García and Le Reste 1987). In tropical and subtropical coastal habitats the penaeid shrimp exploitation plays a major role in the local community economy, due to important revenues that its commercialization generates.

In Mexico penaeid shrimp production occupies the first place among the fishing resources with high economic value, and the national shrimp fleet generates more than 60 000 direct employments (Sierra et al. 2001, García-Borbón et al. 2004). From the total of shrimp landings in Mexico during 2001 (c.a. 95 000 tons) the Pacific coast contributed 75000 tons or $79 \%$ of the national production (Sierra et al. 2001). In contrast, estuarine shrimp contributed only $6 \%$ to that production. In the Gulf 
of Tehuantepec, where the Carretas-Pereyra coastal system is located, the offshore shrimp yield represents $8.5 \%$ of the Mexican Pacific shrimp production. Along the Pacific coast of Mexico eight species of penaeids are exploited, though four of them (Farfantepenaeus californiensis Holmes 1990, F. brevirostris Kingsley 1878, Litopenaeus stylirostris Stimpson 1871 and L. vannamei Boone 1931) constitute more than $90 \%$ of the total capture (Sierra et al. 2001). In the industrial shrimp fishery of the Gulf of Tehuantepec, L. vannamei represents $40 \%$ and it is also the most abundant species in the estuary systems (Medina-Reyna 2001), where it represents $97 \%$ of the shrimp production.

Fishing coastal communities in the Gulf of Tehuantepec base almost entirely their operation (95\% according to Ramos-Cruz 2000) on the exploitation of juvenile shrimp. This activity has taken place for several decades since 1920 (Anonymous 1998), and in spite of its socioeconomic implications for the region, the coastal systems have remained practically unexplored. The need to increase our knowledge on this region of Mexico becomes highly relevant, in light of the significant decline in estuarine shrimp production recorded in the past decade (Anonymous 2000).

Our current knowledge on the estuarine shrimp population of L. vannamei is restricted to the studies conducted by Ramos Cruz (2000) and Medina-Reyna (2001). These authors documented the spatial-seasonal distributional patterns, the abundance and growth rate and age structure of the white shrimp in the Mar Muerto lagoon, Oaxaca-Chiapas.

The estimation of growth, mortality and migratory patterns are essential parameters in any population dynamics study (Guerra and Sánchez 1998). Their determination is essential for designing a fishing management strategy that insures a sustainable fishing exploitation in the area of study. The present study aims to that objective by assessing the environmental influence upon the estuarine population of L. vannamei inhabiting the Carretas-Pereyra coastal system, Chiapas. An attempt is made to determine its annual distribution, abundance patterns, its growth and mortality rates as well as the migratory behavior of the juvenile stages within this complex coastal system.

Study area: Coastal lagoons are shallow aquatic habitats extended behind coastal bars of marine origin, while an estuary is semi-closed coastal body of water with one or more rivers or streams flowing into it, and with a free connection to the open sea (Shepard 1973). Based on these definitions, one can recognize the existence of both physiographic features in the study area. The Carretas-Pereyra system is located on the coast of the Gulf of Tehuantepec between $15^{\circ} 24^{\prime} 45^{\prime \prime}$ and $15^{\circ} 32^{\prime} 24^{\prime \prime} \mathrm{N}$ and $93^{\circ} 04^{\prime} 44^{\prime \prime}$ and $93^{\circ} 06^{\prime} 10^{\prime \prime}$ W (Anonymous 1999). The system encompasses three shallow coastal lagoons interconnected by two meandering channels which open into the Pijijiapan Inlet, that maintains permanent communication with the open sea. Carretas Lagoon, located to the north has the largest surface area $\left(5.6 \mathrm{~km}^{2}\right)$, followed by Pereyra $\left(3.3 \mathrm{~km}^{2}\right)$ located to the west, and Buena Vista $\left(0.8 \mathrm{~km}^{2}\right)$ located to the southeast (De La Lanza 1992, Contreras 1993, Anonymous 1999).

The annual average temperature for the region is $28{ }^{\circ} \mathrm{C}$ with monthly oscillation of less than $5{ }^{\circ} \mathrm{C}$. The dry and rainy seasons are well defined throughout the year: NovemberApril and May-October correspond to dry and rainy periods, respectively. Maximum precipitation $(540.8 \mathrm{~mm})$ occurs in September and a minimum is recorded in January $(4.0 \mathrm{~mm}$, Anonymous 1999). The salinity regime in the lagoons is influenced by tidal flow (100 to 160 $\mathrm{cm}$ amplitude), evaporation rate, and local river runoff (De La Lanza 1992). The area is fringed by a rich mangrove forest (Rhizophora mangle; Laguncularia racemosa; Avicenia germinans), and submerged vegetation basically composed of Typha dominguensis. Sediments are muddypeat and mud-sandy rich in organic matter.

\section{MATERIALS AND METHODS}

Twenty-two sampling sites were selected based on environmental differences (four 
hydrological zones were recognized: central and marginal areas of lagoons, interconnecting channels and estuaries); the position of each site was recorded in a portable GPS. Monthly observations were conducted from March 2004 to August 2005, mostly in day light conditions. Shrimp were captured with the aid of a $4 \mathrm{~m}$ diameter cast net of $10 \mathrm{~mm}$ mesh- size. Ten random casts were made at each site. Temperature and salinity were recorded at each site. Substrate type was characterized in February of 2005. Captured shrimp were counted, sexed, weighed, and measured (carapace length, CL) and later preserved in $70 \%$ ethanol. In the length frequency analysis the following size categories were applied according to Pérez-Farfante (1970 a, b), and Pérez-Castañeda and Defeo (2001): recruits as epibenthic postlarvae $(<8 \mathrm{~mm} \mathrm{CL})$; juvenile (8-15 mm CL) and sub-adults (>15 mm CL). The size distribution for each sample was analyzed using Kernel Density Estimators (KDE), a statistical method proposed by Rosenblatt (1956) and defined as:

$$
\hat{f}(x)=\frac{1}{n h} \sum_{i=1}^{n} K\left[\frac{x-X_{i}{ }^{\prime}}{h}\right.
$$

where,

$$
\begin{aligned}
& \quad \hat{f}(x)=\text { density estimation for variable } \mathrm{x} \\
& \mathrm{n}=\text { inspection number } \\
& \mathrm{h}=\text { bandwidth } \\
& \mathrm{X} \mathrm{i}=\text { length of the } \mathrm{i} \text {-th shrimp specimen } \\
& \mathrm{K}=\text { Kernel function }
\end{aligned}
$$

Kernel Gaussian function was used:

$$
K_{(z)}=\frac{1}{\sqrt{2 \pi}} \exp \left(-\frac{z^{2}}{2}\right)
$$

where,

$$
z=\frac{\left(x-X_{i}\right)}{h}
$$

Optimal bandwidth $\mathrm{h}$ was chosen based on Silverman's rule (1986):

$$
h=\frac{0.9 A}{n^{1 / 5}}
$$

where,

$$
A=\min \left[\left(\frac{\sum\left(X_{i}-x\right)^{2}}{n-1}\right)^{1 / 2},\left(\frac{\text { Fourth }- \text { spread }}{1.349}\right)\right]
$$

The density distribution values were organized by a frequency scale and decomposed in their Gaussian component with a computerized version of the method proposed by Bhattacharya (1967), included in the statistical package Stata software 8.0 (Salgado-Ugarte et al. 1997, Stata Corporation 2003). The shrimp's average growth was estimated by modal progression analysis.

With the estimation of shrimp numbers by cohort (CPUE) in two successive moments $t_{1}$ and $t_{2}$, using Baranov's (1918) equation

$$
\left.Z=\mid \frac{1}{t_{2}-t_{1}}\right)\left|\ln \frac{N\left(t_{1}\right)}{N\left(t_{2}\right)}\right|
$$

the total mortality $(Z)$ coefficients were estimated. To estimate $\mathrm{Z}$ in this equation, it was not necessary to know the absolute values for $\mathrm{N}\left(\mathrm{t}_{1}\right)$ y N $\left(t_{2}\right)$, only their proportion. Catch per unit of effort (CPUE), amount of shrimps captured per cast, is the assumed quantity proportional to the shrimp abundance in the system, N (Sparre and Venema 1997).

For comparative purposes with other studies in which total length (TL) is employed, the CL average length for white shrimp was transformed into TL applying the following equation:

$$
y=4.967265 x+(-2.941976) \quad r^{2}=0.9587
$$

Catalogue number of voucher specimens (lot) is LHUNICACH-C-280-06. 


\section{RESULTS}

Environmental factors: the water temperature in the studied coastal system shows a reduced range $\left(26.87{ }^{\circ} \mathrm{C}\right.$ to $\left.33.34{ }^{\circ} \mathrm{C}\right)$. The difference between the average of the coldest and warmest months was of $6.5^{\circ} \mathrm{C}$ (Fig. 1). However, differences among the monthly averages were significant (ANOVA; $\mathrm{p}<0.0001$ ). The minimum temperature was recorded in February $2005\left(22.9^{\circ} \mathrm{C}\right)$ and the lowest average belonged to January $\left(26.87^{\circ} \mathrm{C}\right)$. The warmest temperature was recorded in August 2004 $\left(36.8^{\circ} \mathrm{C}\right)$ as well as the highest monthly average $\left(33.34^{\circ} \mathrm{C}\right)$. Temperature between sites did
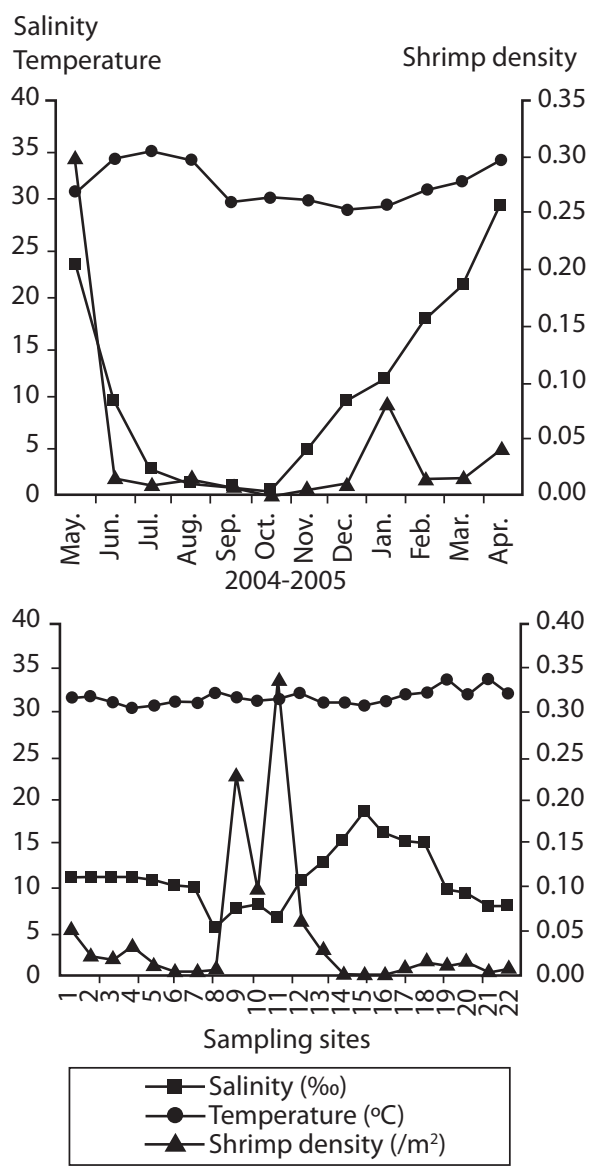

Fig. 1. Variation recorded for shrimp abundance in relation to the season and spatial distribution of temperature and salinity in the Carretas-Pereyra coastal lagoon system. not show significant differences (ANOVA; $\mathrm{p}<0.72$ ). Water salinity had an ample fluctuation range from $0 \%$ in October to $32.8 \%$ in April; the lowest average was registered in October (0.39 \%o) and the highest in April (29.27 $\%$ ). Salinity differences were significant on a monthly basis $(\mathrm{H}=202.15 ; \mathrm{p}<0.0001)$ but these were not significant among sites $(\mathrm{H}=31.23$; $\mathrm{p}=0.0696$ ). Seasonal salinity averages also presents significant differences $(\mathrm{H}=57.84$; $\mathrm{p}<0.0001$ ), being higher during the dry season (15.74\%; std 10.1$)$ than during the rainy season (6.35\%; std 9.3). Considering the salinity monthly average by season, the system can be divided into four categories following "Venice System" classification (Reid and Wood 1961): I limnetic $(<0.5 \%)$ October 2004; II oligohaline $(0.5-<5.0 \%)$ July, August, September and November 2004; III mesohaline $(5.0-<18.0$ $\%$ ) June and December 2004, January and February 2005; IV polyhaline $(18.0-<30.0 \%$ ) May 2004 and March to April 2005. The salinity averages in most of the sampling sites fall within the mesohaline category, except for site 15 (Boca Pijijiapan). The percentage of organic matter $(\mathrm{OM})$ contained in the sediments of the lagoons varied from $0.26 \%$ to $28.52 \%$; most of the sites had high OM contents (3.9 to $28.2 \%$ ). Improvised sites in $\mathrm{OM}$ were located near meandering channels, at the Pijijiapan Inlet and Pereyra Lagoon (sites 8, 12, 15 and 21), whereas the enriched sites corresponded to sites near the Carretas Lagoon (sites 4 and 7). Sandy bottoms were predominant at the above inlet and the connecting channels. The silt-clay fraction varied from $4.79 \%$ to $58.60 \%$; highest contents of silt-clay occurred at Carretas and Buena Vista Lagoons.

Distribution and abundance: a total of 2669 shrimp specimens were collected from the 22 sampling sites. The density fluctuated between 0.001 and $0.302 \mathrm{ind} / \mathrm{m}^{2}$. The highest abundance of shrimp (82\%) was registered in January 2005; other significant percentages (59\%) were registered in June 2004 and February 2005. The maximum density values were registered in May 2004 and January and 
April 2005 (Fig. 1). The density showed significant differences among months $(\mathrm{H}=29.6$; $\mathrm{p}<0.0002$ ), particularly in January. There is significant difference between the seasons $(\mathrm{H}=5.57 ; \mathrm{p}<0.009)$ being the density higher in the rainy season.

The spatial distribution of density was concentrated in Buena Vista Lagoon (sites 10, 11 ), in one of the interconnecting channels ( $\mathrm{La}$ Paluda, site 9), in the estuarine channel (sites 12 and 13), and in Carretas Lagoon (sites 1, 2, 3 and 4) (Fig. 1). However, only sites 9, 10, 11 and 12 showed significant density differences $(\mathrm{H}=66.48 ; \mathrm{p}<0$. 0001) with respect to the others sites.

The localities corresponding to the southeast sector of the system (sites 9,10 and 11) had the highest shrimp density values from May to August and April (Fig. 1). In contrast, in the northern sector (sites 1, 2, 3 and 4) the highest density was recorded in May-June and January; while in the estuarine channel at the central part of the system (sites 12 and 13), a major density was registered in January. In the northwestern sector (sites 17, 18, 19 and 20) maximum shrimp densities were recorded between November and January. The shrimp density estimated in the sectors La PaludaBuena Vista and Carretas had significant differences $(H=39.55 ; p<0.0001)$ with respect the other localities in the coastal system.

In Carretas (sites 1,4) and Buena Vista (site 10) Lagoons the highest capture frequencies were obtained (10 out of 12 samplings); other places with major capture frequencies corresponded to the north part of Buena Vista (site 11) with nine samplings, the Carretas Lagoon central area (site 2), the interconnecting channels La Paluda (site 9) and the East side of Pereyra Lagoon (site 18) with eight samplings. On the other hand, the localities with lowest index of frequency of occurrence were the sites 14, 15 and 16 (La Boquita, Boca Pijijiapan and Pereyra Coyoleño). The sites with the highest values of abundance and frequency, in descending order were 11, 9, 10, 1, 12 and 4. Shrimp abundance showed significant inverse correlation with salinity in the system $(r=-0.42 ; p<0.05)$. No correlation was appreciated with organic matter content $(r=-0.03 ; p>0.05)$ but was significant with the silt content $(\mathrm{r}=0.44 ; \mathrm{p}<0.05)$.

Size composition and migration age: the main recruitment of shrimp epibenthic postlarvae into the coastal lagoon system occurs in January and May but they were not detected in August during two consecutive years. In general, epibenthic shrimp were more abundant from November to May and their presence declines from June to October. Both juvenile and sub-adults were captured during the entire period of sampling reaching peak abundance in January. Their abundance diminished from February to March followed by another peak abundance from April to June, declining again towards the period from July to December (Fig. 2 ). Even though, penaeid shrimp are always present in the system, the abundance pattern of the three development stages (recruit, juvenile and sub-adults) is essentially bimodal. The number of modes detected by monthly sampling varied between two and three and there were 18 generations identified during the 18 months of sampling (Table 1). The minimum modal size for these groups was $2.84 \mathrm{~mm}$ and the maximum was $26.86 \mathrm{~mm}$ of $\mathrm{CL}$ that corresponds to $122.56 \mathrm{~mm}$ of TL. However, it was observed that L. vannamei can reach sizes up to $27.7 \mathrm{~mm} \mathrm{CL}$ (134.65 $\mathrm{mm} \mathrm{TL}$ ), in nearly five months; at this age, L. vannamei emigrates to the adjacent offshore waters (Fig. 3).

Growth and Mortality: the growth rates were estimated within the size interval of 2.84 to $26.86 \mathrm{~mm} \mathrm{CL}$ (Table 1). The cohorts were progressively identified in each month of sampling. The estimated growth rate fluctuated from 0.06 to $0.27 \mathrm{~mm} /$ day $\mathrm{CL}$ ( 0.29 to 1.34 $\mathrm{mm} /$ day TL), with an average of $0.16 \mathrm{~mm} /$ day $\mathrm{CL}$. The average growth rate in CL was similar during the dry and rainy seasons, 0.158 and $0.160 \mathrm{~mm} /$ day, respectively.

Nine individual estimations of total mortality $(\mathrm{Z})$ were obtained in an interval between 0.04 and 0.34 per week. The total mortality $(Z)$ 


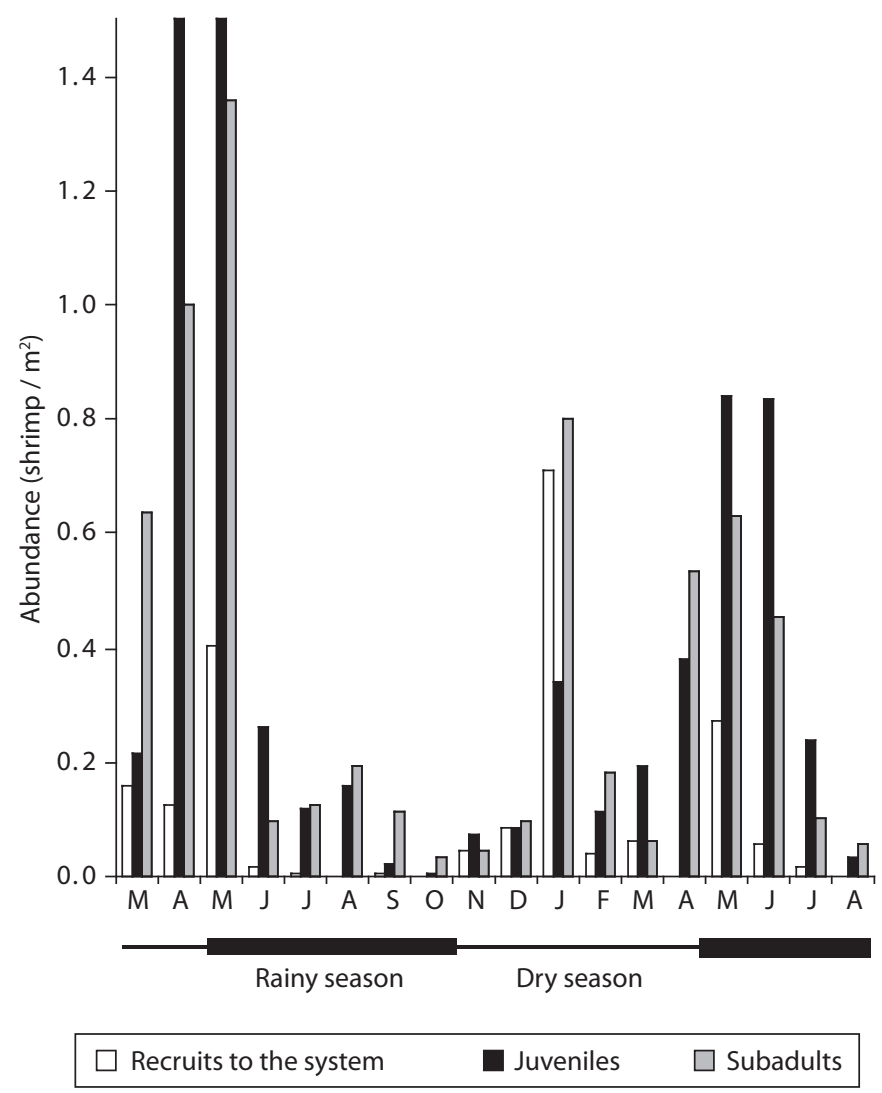

Fig. 2. Abundance pattern for Litopenaeus vannamei in the Carretas-Pereyra coastal lagoon system recorded from March 2004 to August 2005. The abundance of juvenile in April and May 2004 was 3.8 and 4.9 shrimp $/ \mathrm{m}^{2}$ respectively.

was 0.25 . These values of mortality included shrimp in sizes from epibenthic postlarvae (recruits to the system) to sub-adults with sizes below the first capture size for commercial fishing. Therefore, in this case, $\mathrm{Z}$ is equal to $\mathrm{M}$. When the $\mathrm{Z}$ value is transformed to percentage it was obtained a weekly mortality rate from 8.0 to $58.7 \%$ with a general rate of $29.87 \%$.

\section{DISCUSSION}

Distribution and abundance: the shrimp spatial heterogeneity both in distribution and abundance can be attributed to different factors. On one hand, L. vannamei shows an amphibiotic life cycle. The adult stock reproduces

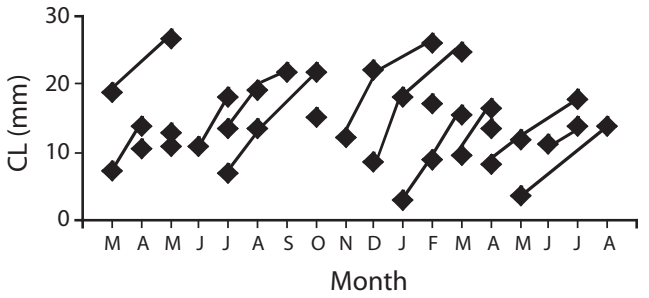

Fig. 3. Monthly distribution of cephalothorax average length of Litopenaeus vannamei recorded in the CarretasPereyra coastal lagoon system (March 2004 to August 2005).

in the sea and the postlarvae and sub-adult use lagoons and estuary systems as nursery grounds. Its physiology is modified throughout this process, evolving particularly its osmo- 
TABLE 1

Growth rate per cohort of Litopenaeus vannamei estimated in the Carretas-Pereyra coastal lagoon system

\begin{tabular}{|c|c|c|c|}
\hline Cohorts & $\begin{array}{c}\text { Range } \\
\text { CL (mm) }\end{array}$ & $\begin{array}{c}\mathrm{K} \\
(\mathrm{mm} / \mathrm{d})\end{array}$ & Season \\
\hline 1 & $7.17-13.84$ & 0.16 & Dry \\
\hline 2 & $18.95-26.86$ & 0.12 & Dry \\
\hline 3 & $10.95-18.50$ & 0.25 & Rainy \\
\hline 4 & $6.88-13.46$ & 0.24 & Rainy \\
\hline 5 & $13.46-21.74$ & 0.14 & Rainy \\
\hline 6 & $13.62-19.28$ & 0.20 & Rainy \\
\hline 7 & $19.28-21.85$ & 0.08 & Rainy \\
\hline 8 & $15.10-22.25$ & 0.13 & $\begin{array}{c}\text { Season change } \\
\text { Rainy-Dry }\end{array}$ \\
\hline 9 & $22.25-26.00$ & 0.06 & Dry \\
\hline 10 & $8.65-18.07$ & 0.27 & Dry \\
\hline 11 & $18.07-24.75$ & 0.12 & Dry \\
\hline 12 & $2.84-8.80$ & 0.21 & Dry \\
\hline 13 & $8.80-15.35$ & 0.24 & Dry \\
\hline 14 & $9.64-16.54$ & 0.20 & Dry \\
\hline 15 & $8.27-11.86$ & 0.12 & Dry \\
\hline 16 & $11.86-17.82$ & 0.11 & $\begin{array}{c}\text { Season change } \\
\text { Dry-Rainy }\end{array}$ \\
\hline 17 & $3.54-13.99$ & 0.12 & $\begin{array}{c}\text { Season change } \\
\text { Dry-Rainy }\end{array}$ \\
\hline 18 & $11.05-13.69$ & 0.09 & Rainy \\
\hline
\end{tabular}

regulation capacity, reason why during its growth they present differences in the estuary environment. In this study, salinity presented a significant inverse correlation versus abundance $(r=-0.42 ; \mathrm{p}<0.05)$. This agrees with the information indicated by García and Le Reste (1987) for another Peneidae species and with the observations made by Medina-Reyna (2001) for L. vannamei in the Mar Muerto Lagoon, near to the studied area. The system presents extreme variations in salinity (0.0-31.0 $\%$ ) in its different sectors, the normal river discharge helps to maintain mesohaline water conditions. However, seasonal precipitation exerts a direct influence upon the salinity regime, creating at least four haline categories from which, the mesohaline and polyhaline coincide with the months (January and April) in which the highest juvenile production was recorded. The rainy season presented higher shrimp average abundance but the highest frequencies and occurrences were registered during the dry season. Similarly, the significant shrimp abundance obtained in May -first month of the rainy season- corresponded to the major capture average for this season.

On the other hand, shrimp migration is not only promoted by salinity fluctuations. The selection of an adequate substrate for postlarvae settling, the environment trophic richness and the hydrology are additional factors that account for penaeid shrimp migratory patterns (García and Le Reste 1987). In the HuizacheCaimanero system, during the growth stage, Edwards (1977) observed higher concentration of epibenthic postlarvae in channels and mangrove areas, probably in response to low daylight intensity. This author also registered high concentrations of juvenile along the lagoons' periphery apparently associated to the emigration period.

The river discharge into a coastal lagoon system such as Carretas-Pereyra, not only contributes to originate a salinity gradient but also constitutes an important source of nutrients; both conditions promote the settlement and growth of penaeid shrimp (Yáñez-Arancibia 1986, RamosCruz 2000, Medina-Reyna 2001). Sediments of silty and muddy type, rich in organic matter (3.9-28.5\%), seem also to enhance juvenile concentrations in the area of study. The western sectors of Carretas and Buena Vista Lagoons included the most productive sites in which shrimp attain high densities since they represent emigration routes, near the narrow channels that open into the main inlet (Pijijiapan Inlet). A similar pattern of abundance and distribution was described by Medina-Reyna (2001) in the Mar Muerto Lagoon.

Size composition and migration age: the analysis of the size distribution revealed that the pattern of postlarvae immigration is 
consistent for the two successive years studied. Thus for instance, strong immigration pulses of postlarvae occur during the dry season, when the prevailing conditions of reduced precipitation and weak river discharge into the coastal lagoon system, apparently facilitate such a process. It is known that temperature variation may trigger shrimp spawning in offshore waters (Lindner and Cook 1970). In the studied area, significant temperature oscillations were recorded from December to February, a period that marks the onset of the dry season (Fig. 2). The described immigration pattern is congruent with similar studies conducted in the Gulf of Tehuantepec by Medina-Reyna et al. (1998) and Medina-Reyna (2001), and D' Croz et al. (1979) in the Pacific coast of Panama. Edwards (1977), in the northwestern coastal lagoons of Mexico, established a correlation between the immigration of shrimp postlarvae and the first months of the rainy period extended from June to July.

The annual bimodal abundance pattern of juvenile shrimp appears in synchrony with the dry season. Significant peak values were detected in January and July, though a third reduced mode was noted between February and March. Empirical knowledge on the part of local fishermen about the timing of shrimp postlarvae arrival and juvenile aggregation in the area of study, has historically established the months of maximum fishing effort in February-April and July-August, just prior to the onset of the above two processes. In the offshore waters of the Carretas-Pereyra system, shrimp spawning and planktonic immigration are processes intimately connected and presumably, they also exhibit an annual bimodal pattern similar to that described for juvenile stages. The range size and age of emigrating juvenile shrimp (145 mm TL; 4.5 months) are comparable to those reported by Ramos-Cruz (2000) the Mar Muerto Lagoon, Oaxaca.

The shrimp emigration process in the coastal lagoon system of Carretas-Pereyra seems continue throughout the year, hence the lack of positive correlation between the emigration size and season of the year. Shrimp fishing effort in the lagoon complex intensifies when salinity changes occur and this coincides with certain lunar phases: full moon and new moon. Presumably, shrimp emigration from nursery grounds is promoted by several factors whose interaction is different in tropical environments (Garcia and Le Reste 1987). Nonetheless, the new moon and the moon's light intensity have frequently been invoked to explain shrimp emigration (Beardsley 1970, García and Le Reste 1987, Edwards 1977).

Growth: rather than relying on the traditional length frequency distribution analysis to determine shrimp's growth, the Kernel Density Estimator (KDE) was employed to avoid the dependence on the origin, interval width, discontinuity and the use of fixed width intervals (Salgado-Ugarte et al. 1997).

The Kernel Density Estimator (KDE) solves these inconveniences and the estimators can be implemented with a wide interval adjustable to the number of data; additionally, the analysis avoids subjectivity since it provides guidelines to select less arbitrarily the histogram or frequency polygon to be used (Sanvicente-Añorve et al. 2003). A KDE's inconvenience is the great number of calculations that it requires. Scott (1985) suggested a form to overcome this problem: the procedure called "Average Shifted Histogram" (ASH). Later, Härdle and Scott (1988) developed the most general structure denominated "Weighed Average of Rounded Points" (WARP). This approach was used in this study to calculate the KDEs using the programs published by Salgado-Ugarte et al. (1997). The Silverman amplitude optimal bandwidth is designed for data with Gaussian distribution (Silverman 1986). This value is large when it is applied to biased or multimodal distributions. However, in these cases the optimal bandwidth can serve as a reference that allows recovering the dominant mode.

The growth rates varied widely; several authors recognize that this variation is influenced by the residence time of shrimp in the lagoon systems, the salinity, the temperature and the food availability (Edwards 1977, García 
and Le Reste 1987, Ramos-Cruz 2000, MedinaReyna 2001). However, the values estimated in this study are somewhat similar to the reported average values calculated in previous studies for coastal lagoons in the Mexican Pacific. Our estimations are close to the growth data reported by Ramos-Cruz (2000) and Medina-Reyna (2001) for L. vannamei in the Mar Muerto system from the Gulf of Tehuantepec (Table 2). It is important to emphasize that cohorts did not exhibit seasonal significant differences in their growth.

Mortality: the calculated mortality values for $L$. vannamei in the coastal lagoon system of Carretas-Pereyra may seem high ( $Z$ total $=25 \%$ per week). Yet, the mortality rate in the system is slightly lower to the indicated by Edwards (1977) for juveniles L. vannamei in the Huizache-Caimanero lagoons system ( $Z=44 \%$ and $M=41 \%$ weekly). This author partially attributes such high estimated rate to the shrimps lost from experimental enclosures. In the assessment made by Chávez (1979) of the offshore shrimp stock in the Gulf of Tehuantepec, a weekly $\mathrm{Z}$ between 0.05 and 0.22 was recorded, which approaches the $Z$ values obtained for juvenile shrimp. In other studies, it has been calculated that total juvenile shrimp mortality can reach up to $90 \%$ (Edwards 1977), considering the difference between the postlarvae that arrive into the lagoon and the total fishing mortality. We assumed that mortality can vary in different parts of the lagoon system, and perhaps it is significant within the lagoons and channels where also different shrimp stages congregate. The total mortality herein reported may seem underestimated due to the absence in our analysis of data on postlarvae immigration and fishing mortality (F). Future research efforts ought to determine these parameters to validate our preliminary mortality estimates. The values of mortality that we considered belong to cohorts in different degrees of development.

In conclusion, this study confirms that the recruitment of shrimp postlarvae is continuous in the southeastern coast of the Mexican
TABLE 2

Comparison of average growth rates ( $\mathrm{mm} /$ day) for Litopenaeus vannamei between the Carretas-Pereyra coastal lagoon system and other lagoons in the Pacific coast of Mexico

\begin{tabular}{|c|c|c|}
\hline Lagoon & Highest & Lowest \\
\hline Huizache-Caimanero $(1969)^{1}$ & 2.85 & 0.88 \\
\hline Huizache-Caimanero (1973) $)^{1}$ & 1.96 & 0.88 \\
\hline Huizache-Caimanero (1973-74)1 & 1.64 & 0.51 \\
\hline Huizache-Caimanero $(1974)^{1}$ & 1.54 & 0.53 \\
\hline Huizache-Caimanero $(1977)^{2}$ & 2.00 & 0.01 \\
\hline Mar Muerto $(2000)^{3}$ & 1.27 & 0.13 \\
\hline Mar Muerto $(2001)^{4}$ & 1.21 & 0.20 \\
\hline Carretas-Pereyra (thi study) & 1.34 & 0.29 \\
\hline $\begin{array}{ll}1 & \text { Cited in Medina-Reyna (2001); } \\
2 & \text { Edwards (1977); } \\
3 & \text { Ramos-Cruz (2000); } \\
4 & \text { Medina-Reyna (2001). }\end{array}$ & & \\
\hline
\end{tabular}

Pacific. However, although small individuals were observed the whole year, the length frequency analysis applied in two fishing seasons allowed the recognition of two main cohorts: one of them appearing before the fishing season in January, and the other at the end of the season in May. Therefore, a bimodal shrimp recruitment associated to the conditions prevailing during the dry season is recognized. Such pattern of recruitment, obtained through the modal progressions analysis occurs from December to January and from March to May. The annual reproduction variation is similar to the recruitment pattern described for juvenile shrimp. No clear correlation was distinguished between emigration size and season of the year or water temperature. Similarly, the juvenile shrimp growth rate seems independent of seasonal changes.

\section{ACKNOWLEDGMENTS}

We thank the personnel who kindly assisted in field work and the processing of samples. 
Thanks are extended to the CONANP and the staff of La Encrucijada Biosphere Reserve, for the facilities provided during this study. The first author acknowledges V. Rivera for his assistance in the elaboration of this manuscript. The support rendered by the fishermen's cooperative societies of La Encrucijada is greatly appreciated. This work was sponsored by the Escuela de Biología, Universidad de Ciencias y Artes de Chiapas and by Fondo Sectorial SAGARPA-CONACYT project 160 , 2003-002. This study is part of the first author Doctoral thesis in the Posgrado en Ciencias Biológicas, Universidad Nacional Autónoma de México.

\section{RESUMEN}

Se estudió el crecimiento, la mortalidad y el patrón de migración del camarón Litopenaeus vannamei Boone 1931 en el sistema lagunar costero Carretas Pereyra, México. La distribución espacial y la abundancia fueron analizadas con relación a la salinidad, temperatura y substrato. De marzo de 2004 a agosto de 2005 se recolectó un total de 2669 camarones con un muestreo mensual en 22 sitios. Los jóvenes se hallaron todo el año en el sistema lagunar costero, con densidades entre 0.001 y $0.302 \mathrm{ind} / \mathrm{m}^{2}$. La tasa de crecimiento diaria fue de 0.06 a $0.27 \mathrm{~mm}$ longitud del cefalotórax (CL) y no se apreciaron diferencias significativas entre estaciones. La mortalidad total $(Z)$ semanal estuvo entre 0.04 y 0.34 . Reclutas, jóvenes y subadultos presentan un patrón de distribución bimodal regulado por las condiciones prevalecientes durante la estación de estío. Los valores máximos de abundancia de los estadios juveniles se presentan en diciembre-enero y marzo-mayo. La abundancia presentó una correlación significativa inversa con la salinidad $(\mathrm{r}=-0.42 ; \mathrm{p}<0.05)$ y positiva $(\mathrm{r}=0.44$; $\mathrm{p}<0.05$ ) con el contenido de limo. No se distinguió una clara correlación entre la talla de emigración, la estación del año y la temperatura del agua.

Palabras clave: Litopenaeus vannamei, dinámica poblacional, lagunas costeras, México.

\section{REFERENCES}

Anonymous. 1998. Manejo y Conservación de Cuencas Compartidas entre Las Reservas de la Biosfera "El Triunfo" y "La Encrucijada", Chiapas, México. "Estudio Socioeconómico en la Cuenca Hidrológica de Pijijiapan, Chiapas", Informe Final IDESMAC,
Instituto de Historia Natural, Reserva de La Biosfera la Encrucijada, Chiapas, México.

Anonymous. 1999. Programa de Manejo. Reserva de la Biosfera La Encrucijada". Instituto Nacional de Ecología, SEMARNAP, México D.F., México.

Anonymous. 2000. Anuario Estadístico de Pesca. 1999. Secretaría de Medio Ambiente Recursos Naturales y Pesca, Mazatlán, Sinaloa, México.

Contreras, E.F. 1993. Ecosistemas Costeros Mexicanos. CONABIO-UAM Iztapalapa, México D.F., México.

Chávez, E.A. 1979. Diagnosis de la pesquería de camarón del Golfo de Tehuantepec, Pacífico Sur de México. An. Centro Cienc. Mar Limnol., UNAM, México D.F., México.

D’ Croz, L., F. Chérigo \& N. Esquivel. 1979. Observaciones sobre la biología y pesca del camarón blanco (Penaeus spp.) en el pacífico de Panamá. An. Centro Cienc. Mar y Limnol. Univ. Nal. Autón. México. 6: 45-58.

De La Lanza, E.G. 1992. Oceanografía de Mares Mexicanos. AGT. México D.F., México.

Edwards, R.R.C. 1977. Field experiments on growth and mortality of Penaeus vannamei in a Mexico coastal lagoon complex. Estuarine Coast. Mar. Sci. 5: 107-121.

García, S. \& L. Le Reste. 1987. Ciclos vitales, dinámica, explotación y ordenamiento de las poblaciones de camarones peneidos costeros. FAO Documento Técnico de Pesca, No. 203, Roma, Italia.

García-Borbón, J.A., J. Madrid-Vera, S. Ramos-Cruz, A.R. García-Juárez, D. Chávez-Herrera, D. CastroCastro, E. Zárate-Becerra, L.F. Beléndez-Moreno, E. Morales-Bojórquez, P. Loreto-Campos, S. Hernández, A. Ramos-Montiel, M. Anguiano-Carrazco \& C. Alvarado-Sarabia. 2004. Inicio de la temporada de veda 2004 para la pesquería de camarón del océano pacífico mexicano. Informe de Investigación, Dirección General de Investigación Pesquera en el Pacífico Norte. Instituto Nacional de la Pesca, SAGARPA, Mazatlán, Sinaloa, México.

Guerra, S.A. \& J.L. Sánchez. 1998. Fundamentos de explotación de recursos vivos marinos. ACRIBIA, Zaragoza, España.

Lindner, M.T. \& H.T. Cook. 1970. Synopsis of biological data on the white shrimp Penaeus setiferus (Linnaeus, 1767). FAO Fish. Rep. 57: 1439-1469.

Medina-Reyna, C.E., O. Morales-Pacheco \& H .SalinasOrta. 1998. El reclutamiento de las postlarvas 
de camarón (Penaeus vannamei) en el Golfo de Tehuantepec: una revisión. Cienc. Mar, México 2: 33-44.

Medina-Reyna, C.E. 2001. Growth and Emigration of White Shrimp, Litopenaeus vannamei, in the Mar Muerto Lagoon, Southern Mexico. Naga, The ICLARM Quarterly 24: 30-34.

Pérez-Castañeda, R. \& O. Defeo. 2001. Population Variability of Four Sympatric Penaeid Shrimps (Farfantepenaeus spp.) in Tropical Coastal Lagoon of Mexico. Est. Coastal Shelf Sci. 52: 631-641.

Pérez-Farfante, I. 1970a. Diagnostic characters of juveniles of the shrimp Penaeus aztecus aztecus, $P$. duorarum duorarum and P. brasilensis (Crustacea, Decapoda, Penaeidae) Spec. Scient. Rep. U.S. Fish Wildl Serv. Fisheries, 599.

Pérez-Farfante, I. 1970b. Características diagnósticas de los jóvenes de Penaeus aztecus subtilis, P. duorarum notialis y $P$. brasilensis (Crustacea, Decapada, Penaeidae). Separatas Memorias Sociedad Ciencias Naturales La Salle 30: 159-182.

Ramos-Cruz, S. 2000. Composición por tallas, edad y crecimiento de Litopenaeus vannamei (Natantia: Penaeidae), en la laguna Mar Muerto, OaxacaChiapas, México. Rev. Biol. Trop. 48: 873-882.

Reid, K.G. \& R.D. Word. 1961. Ecology of Inland Waters and Estuaries. D. van Nostrand Co., New York, USA.

Sanvicente-Añorve, L., I.H. Salgado-Ugarte \& M. CastilloRivera. 2003. The use of kernel density estimators to analyze length-frequency distributions of fish larvae, p. 419-430. In I.H. Browman \& A.B. Skiftesvik (eds.). The Big Fish Bang: Proceeding of the $26^{\text {th }}$ Annual Larval Fish Conference. Institute of Marine Research, Bergen, Norway.

Salgado-Ugarte, I.H., M. Shimizu \& T. Taniuchi. 1997. Nonparametric assessment of multimodality for univariate data. Stata Technical Bulletin 38: 27-35.

Silverman, B.W. 1986. Density estimation for statistics and data analysis. Chapman and Hall, London, United Kingdom.

Sierra, P., C. Acosta, J.A. García, A.R. García, A. Liedo, J.M. Melchor, S. Ramos, A. Rosas, M.P. Toledo \& E. Zárate. 2001. Camarón del Océano Pacífico, p. 5-50. In Sustentabilidad y Pesca Responsable en México. Evaluación y Manejo 1999-2000. Instituto Nacional de la Pesca, SAGARPA, Mazatlán, Sinaloa, México.

Shepard, F.P. 1973. Submarine geology. Harper \& Row, New York, USA.

Sparre, P. \& S.C. Venema. 1997. Introducción a la evaluación de recursos pesqueros tropicales. Parte 1: Manual. FAO documento técnico de pesca 306/1 Rev. 2 DANIDA. Organización de las Naciones Unidas para la Agricultura y la Alimentación, Roma, Italia.

Stata Corporation. 2003. Stata Statistical Software for Windows: Release 8.0. College Station, TX., USA.

Yáñez-Arancibia, A. 1986. Ecología de la Zona Costera. Análisis de siete tópicos. AGT, México D.F., México. 